\title{
БИОЛОГИЧЕСКИ АКТИВНЫЕ КОМПЛЕКСЫ МЕДИ(II) С ПИРОСЛИЗЕВОЙ КИСЛОТОЙ
}

\author{
К.А. Кошенскова'
}

\author{
${ }_{1}^{1}$ Российский химико-технологический университет им. Д.И. Менделеева, г. Москва \\ ${ }^{2}$ Институт общей и неорганической химии им. Н.С. Курнакова РАН, г. Москва \\ ${ }^{3}$ Институт общей генетики им. Н.И. Вавилова РАН, г. Москва
}

DOI: 10.19163/MedChemRussia2021-2021-353

E-mail: ksenia-18.11.99@mail.ru

Проблема туберкулеза остается второй после ВИЧ среди инфекционных заболеваний. Все пути создания эффективных средств борьбы с Mycobacterium tuberculosis (МБТ, палочка Коха) имеют недостатки из-за его фенотипической гетерогенности, повышенной адаптивной способности, а также наличием системы генов природной лекарственной устойчивости, что обеспечивает патогену аномально высокую выживаемость в неблагоприятных условиях. Одной из попыток решения данной проблемы является использование координационных молекул с новым механизмом действия. В качестве комплексообразователя нами выбрана медь, поскольку в живых системах выполняет целый ряд важных функций, например, является компонентом дыхательной цепи, участвует в каскаде ферментативных реакций. Основной органической молекулой выступила 2-фуранкарбоновая кислота, а также для усиления биологической активности использовались N-донорные лиганды (пиридин (ру), 2,2'- и 4,4' бипиридин (bpy), 1,10-фенантролин (phen), 4-фенилпиридин (рhру), 3-аминопиридин ( $\mathrm{NH}_{2}$ py)). Цель данного исследования заключалась в разработке способов получения комплексов Сu(II) и определение биологической активности in vitro в отношении штаммов микобактерий - непатогенного Mycolicibacterium Smegmatis, патогенного МБТ H37Rv и SCOV3 (клетки рака яичника). Был получен ряд моно- и биядерных комплексов состава $\left[\mathrm{Cu}_{2}(\mathrm{Fur})_{4}(\mathrm{~L})_{\mathrm{x}}\right]$ ( $\left.\mathrm{L}=\mathrm{H}_{2} \mathrm{O}(1), \mathrm{CH}_{3} \mathrm{CN}(2) ; \mathrm{x}=1,2\right) ;\left[\mathrm{Cu}(\mathrm{Fur})_{2} \mathrm{~L}\left(\mathrm{H}_{2} \mathrm{O}\right)\right]$ и $\left[\mathrm{Cu}_{2}(\mathrm{Fur})_{4} \mathrm{~L}_{2}\right]$ ( $\mathrm{L}=$ py (3), bpy (4), phen (5), phpy (6), $\mathrm{NH}_{2}$-рy (7)). При проведении испытаний на биологическую активность in vitro в отношении непатогенного штамма M. Smegmatis комплекс 5 c phen [Cu(fur) $)_{2}(1,10-$ phen)] показал высокую биоактивность (минимальная ингибирующая концентрация (МИК) составила 2 мкг/диск), что в несколько раз превышает активность рифампицина (10 мкг/диск) и изониазида (100 мкг/диск) - препараты первого ряда лечения туберкулеза. Кроме того, для комплексов $2\left[\mathrm{Cu}_{2}(\mathrm{Fur})_{4}\left(\mathrm{CH}_{3} \mathrm{CN}\right)_{2}\right]$ и $\mathbf{5}$ [Cu(fur) ${ }_{2}$ phen] была измерена противоопухолевая активность на клетках рака яичников. Результаты экспериментов показали, что $\mathrm{IC}_{50}$ для 2 составила $>100$ нмоль, тогда как для $\mathbf{5}-3.3$ нмоль, что в два раза эффективнее чем цисплатин (6.2 нмоль). Таким образом, полученный комплекс 2 является кандидатом для расширенных биологических испытаний.

Работа выполнена при финансовой поддержке РНФ (20-13-00061). 